\title{
Terrestrial invertebrates in environmental assessments: A decade of environmental impact studies in the influence area of the Atlantic Rainforest in Rio de Janeiro State, Brazil
}

\section{Rafael Alves Esteves ${ }^{1}$ and Ronilson José da Paz ${ }^{2}$}

\begin{abstract}
${ }^{1}$ Universidade do Estado do Rio de Janeiro. Departamento de Ecologia. Rua São Francisco Xavier, 524. Pavilhão Haroldo Lisboa da Cunha, 2o andar. Rio de JaneiroRJ, Brasil (CEP 20550-900). E-mail: estevesralves@gmail.com.

${ }^{2}$ Universidade Federal da Paraíba. Centro de Ciências Exatas e da Natureza. Programa de Pós-Graduação em Desenvolvimento e Meio Ambiente. Caixa Postal 5063. João Pessoa-PB, Brazil (CEP 58051-900).
\end{abstract}

\begin{abstract}
Invertebrates constitute a megadiverse animal group and abundant in virtually every terrestrial and aquatic ecosystem, performing functions and providing services indispensable to the environment. In this paper, we evaluated how terrestrial invertebrates were treated in the Environmental Impact Assessments submitted to the environmental agency in Rio de Janeiro, state fully inserted at Atlantic Rainforest biome. We analyzed environmental studies developed by companies with new industrial projects presenting potential environmental impact in the period of 2008 to 2018. Only ten (14\%) studies considered terrestrial invertebrates in the biotic diagnostic assessments of fauna. Arthropoda was the only one Phylum considered as terrestrial invertebrates in the studies analyzed, with Class Insecta present in all of them, and Arachnida present in two studies. The insects of the Orders Diptera, Hymenoptera, Coleoptera, Lepidopetra, Hemipetra, Orthopetra and Odonata were the most frequent in the studies. The lack of interest in the conservation of terrestrial invertebrates demonstrates the fragility of the public authorities in issues related to biodiversity conservation strategies of these animals and exposes the urgent need for investment in the formation of human resources specialized in biodiversity conservation.
\end{abstract}

Keywords: Conservation strategy; Biodiversity management; Applied ecology; Topsoil Biology.

Resumo. Invertebrados terrestres nas avaliações ambientais: uma década de estudos de impacto ambiental na área de influência da Mata Atlântica do Estado do Rio de Janeiro, Brasil. Os invertebrados constituem um grupo animal megadiverso e abundante em praticamente todos os ecossistemas terrestres e aquáticos, desempenhando funções e fornecendo serviços indispensáveis ao meio ambiente. Neste artigo,
Received

November 06, 2019

Accepted

December 31, 2019

Released

December 31, 2019

Full Text Article

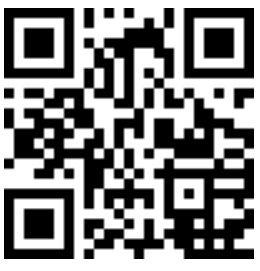

ORCID

(1) 0000-0002-0934-8922

Rafael Alves Esteves

(D) 0000-0002-4990-4495

Ronilson José da Paz 
avaliamos como os invertebrados terrestres foram tratados nas Avaliações de Impacto Ambiental submetidas ao órgão ambiental do Rio de Janeiro, estado totalmente inserido no bioma Mata Atlântica. Analisamos estudos ambientais desenvolvidos por empresas com novos projetos industriais que apresentam potencial impacto ambiental no período de 2008 a 2018. Apenas dez (14\%) estudos consideraram invertebrados terrestres nas avaliações bióticas de diagnóstico da fauna. Arthropoda foi o único Filo considerado invertebrado terrestre nos estudos analisados, com a Classe Insecta presente em todos eles e Arachnida presente em dois estudos. Os insetos das Ordens Diptera, Hymenoptera, Coleoptera, Lepidopetra, Hemipetra, Orthopetra e Odonata foram os mais frequentes nos estudos. A falta de interesse na conservação de invertebrados terrestres demonstra a fragilidade do poder público em questões relacionadas às estratégias de conservação da biodiversidade desses animais e expõe a necessidade urgente de investimento na formação de recursos humanos especializados em conservação da biodiversidade.

Palavras-chave: Estratégias de conservação; Gestão da biodiversidade; Ecologia aplicada; Biologia do solo.

\section{Introduction}

From the 1970s, countries began to consider on their public policies the focus on preventing environmental problems. In Brazil, the consolidation of preventive environmental management instruments was only highlighted with the publication of the National Environmental Policy in 1981 (Almeida, 2015). This policy instituted the Environmental Impact Study (EIA) as an instrument of control and prevention of environmental risks associated to the industrial processes necessary for the environmental licensing of all activities capable of cause significant environmental degradation. The elaboration of EIA became required to authorizes the location, installation, expansion and operation of ventures and activities that use environmental resources, which are actually or potentially polluting or capable, in any way, of causing environmental degradation (Brasil, 1986).

The objective of the EIA is to describe the environmental impacts arising from the implementation of projects and it must present the environmental diagnosis of the influence area of the venture, considering the physical environment (soil, subsoil, surface and groundwater, climate, etc.), the socioeconomic environment (use and land occupation, archaeological sites, economics, education, health etc.) and the biological environment (ecosystems, flora, fauna, etc.), environmental impact analysis, mitigation and compensatory measures and environmental programs (Brasil, 1981; Brasil, 1997, Attanasio Jr., 2015).

In the environmental diagnosis, the biotic assessment is related to biological and ecological aspects of populations and communities. Faunal surveys demand specialists in various zoological groups, usually ornithologists (birds), mastozoologists (mammals), herpetologists (reptiles and amphibians), ichthyologists (fish) and, eventually entomologists (insects) (Garcia and Candiani, 2017). The species are normally categorized according to degree of sensitivity to anthropic interference, dependence on forest environments, endemism, identification of endangered 
species and rare and bioindicator species.

The effectiveness of the EIA in decision making has been criticized by several authors (Oliveira and Bursztyn, 2001; O'Faircheallaigh, 2010; Almeida et al., 2016; Almeida et al., 2019). Among the criticisms pointed out is the low quality of environmental studies designed to obtain licenses, which contributes to the delay in decision making, as well as by making the wrong decisions. One of the reasons for criticism in the EIAs is regarding to the fauna survey. Quantitative faunal surveys such as population censuses are rare because they require field effort and time by specialists, rarely available in the completion of the EIAs (Sánchez, 2013). The main problems encountered in the EIAs are the lack of identification of breeding areas and lack of information related to behavior aspects, ecological interactions, key and bioindicator species (Sherer, 2011), as well as methodological problems, ranging from lack of experts to poor experimental design, selection of methods and the absence of methodological standardization in driving of faunal inventories in EIAs (Wegner et al., 2005; Thompson, 2007; Duarte et al., 2017; Lacy et al., 2017).

In this paper, we evaluated how terrestrial invertebrates have been treated in the EIAs submitted to the environmental agency in Rio de Janeiro, under the domain of the Atlantic Rainforest biome. Given the high diversity of terrestrial invertebrates and the importance of these animals drive in ecosystems, our specific goals were (1) to identify the terrestrial invertebrate groups considered in the studies, (2) to evaluate data collection methods, and (3) to promote discussion of invertebrate's conservation.

\section{Materials and methods}

To evaluate how the terrestrial invertebrates have been treated in the environmental impact studies, we analyzed the information submitted and available in the database of the Instituto Estadual do Ambiente do Rio de Janeiro (INEA), an organ of the State of Rio de Janeiro Government, linked to the State Secretariat of Environment and agency responsible for environmental licensing at the state level.

In this analysis we included environmental studies developed by companies with new industrial projects presenting potential environmental impact and we evaluated the studies submitted to the INEA from 2008 to 2018 , comprising a decade of database in all state territory.

The focus of the analysis in the environmental studies was the section of diagnosis of the biotic environment, which consist in the flora and ecosystems, where we collected information about the phytophysiognomic formations of influence areas of the future enterprises and, mainly, in fauna, where we analyzed the animal groups that were considered in the studies, as well as the methodologies that the authors used to obtain the data.

Rio de Janeiro state is fully inserted in the Atlantic Rainforest biome and currently the forest remnants occupy about $20,9 \%$ of the total area of the state, represented for the diverse ecosystems associated with the biome: dense ombrophylous forest, deciduous forest, seasonal forest semideciduous (or "Mata de Tabuleiros"), mangroves, restingas, altitude fields and swamps (Fundação SOS Mata Atlântica e INPE, 2017). Knowing how fauna is represented in environmental impact studies helps in the development of biodiversity conservation strategies in areas affected by industrial projects. Thus, the conservation of biodiversity in the influenced areas of these projects in Rio de Janeiro state represents a major challenge due to the high level of fragmentation of the Atlantic Rainforest biome. Most of the remnants are in small fragments, poor known and not protected, mostly inserted in intensely 
anthropized landscapes (Fidalgo et al., 2007). Regarding the fauna evaluated in the EIAs, the central question of this analysis was: Have terrestrial invertebrates been considered in environmental assessments?

The analyzed EIAs included public and private projects, new and expanding, prepared by different consulting firms and encompassing industrial activities of dam, construction, energy, hospitality, infrastructure, allotment, mining, naval, oil and gas, ports, steel industry and waste treatment, in all regions of the Rio de Janeiro State.

\section{Results}

We analyzed 71 environmental impact studies of industrial projects in municipalities in all administrative regions of the Rio de Janeiro state. Only ten studies $(14 \%)$ considered terrestrial invertebrates in the biotic diagnostic assessments of fauna (Figure 1).

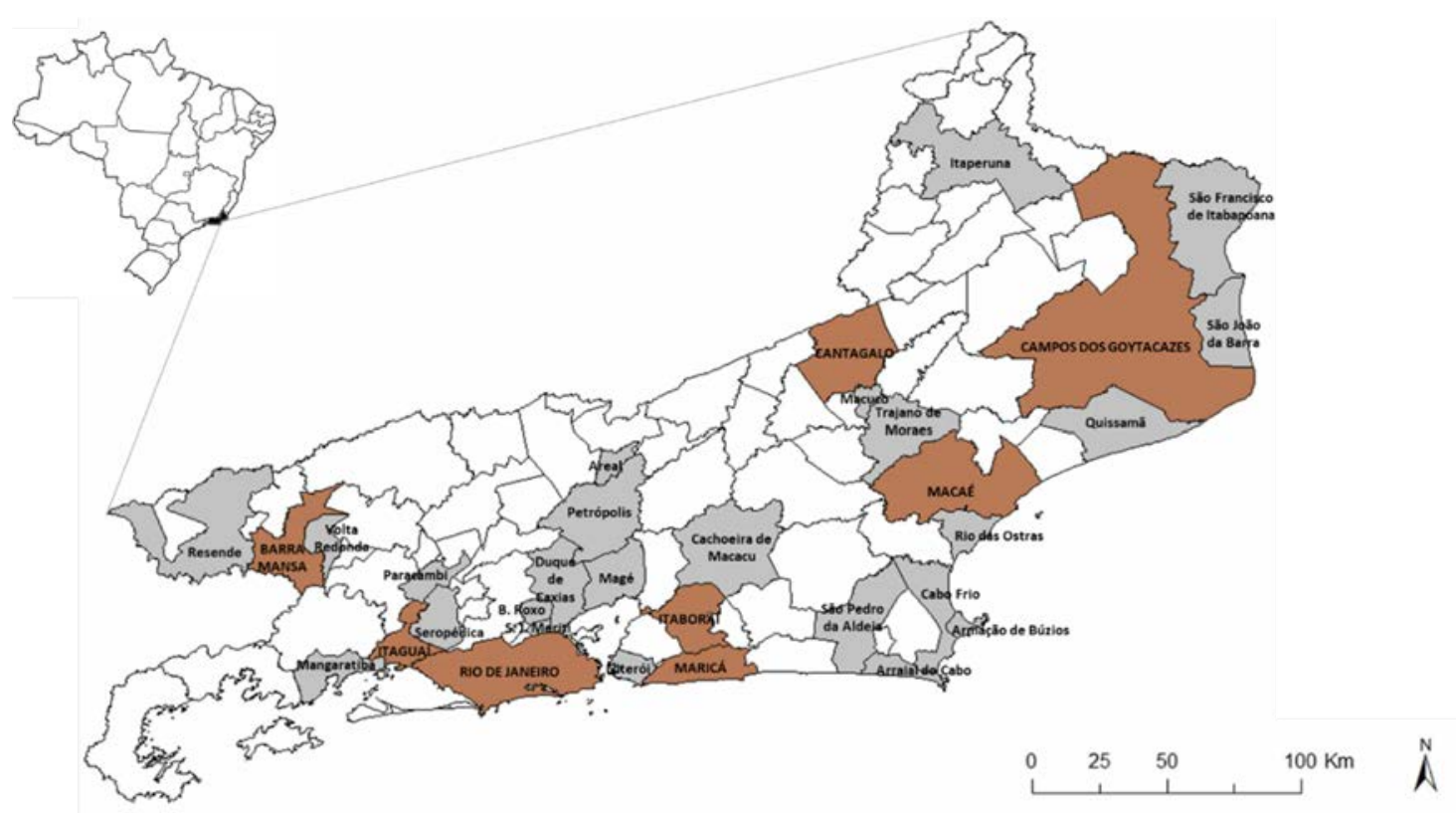

Figure 1. Municipalities with environmental impact studies of industrial projects submitted to the INEA in 2008-2018. In brown: municipalities with terrestrial invertebrates considered in the environmental studies.

Among the ten environmental impact studies that considered terrestrial invertebrates in the faunal surveys, two studies were related to the construction activity, one of energy, one of infrastructure, one of mining, one of naval, one related to port and three related to landfills. These projects are in the Municipalities of Barra Mansa, Campos dos Goytacazes, Cantagalo, Itaboraí, Itaguaí, Macaé, Maricá and Rio de Janeiro (Table 1). 
Table 1. Total of environmental impact studies submitted and available in the INEA database from 2008 to 2018 . In bold the studies that considered terrestrial invertebrates.

\begin{tabular}{|c|c|c|c|c|c|}
\hline ID & Year & Industry & Activity & Municipality & $\begin{array}{c}\text { Consider } \\
\text { terrestrial } \\
\text { invertebrate? }\end{array}$ \\
\hline 1 & \multirow{5}{*}{2008} & Allotment & Real estate development & Armação de Buzios & No \\
\hline 2 & & $\begin{array}{l}\text { Waste } \\
\text { treatment }\end{array}$ & Landfill & Itaboraí & Yes \\
\hline 3 & & Energy & $\begin{array}{l}\text { Small hydroelectric power } \\
\text { station }\end{array}$ & $\begin{array}{l}\text { Macuco e Trajano de } \\
\text { Moraes }\end{array}$ & No \\
\hline 4 & & Port & Port operations & São João da Barra & No \\
\hline 5 & & Energy & Power plant & São João da Barra & No \\
\hline 6 & 2009 & $\begin{array}{l}\text { Waste } \\
\text { treatment }\end{array}$ & Industrial landfill & Quissamã & No \\
\hline 7 & \multirow{12}{*}{2010} & Steel industry & Steel mill & São João da Barra & No \\
\hline 8 & & Energy & Power Plant & São João da Barra & No \\
\hline 9 & & Energy & Power plant & Seropédica & No \\
\hline 10 & & Naval & $\begin{array}{l}\text { Vessel construction and } \\
\text { repair }\end{array}$ & São João da Barra & No \\
\hline 11 & & Port & Waterway terminal & Rio de Janeiro & No \\
\hline 12 & & Port & Waterway terminal & Rio de Janeiro & No \\
\hline 13 & & Port & Waterway terminal & Rio de Janeiro & No \\
\hline 14 & & Naval & $\begin{array}{l}\text { Vessel construction and } \\
\text { repair }\end{array}$ & Niterói & No \\
\hline 15 & & Port & Maritime terminal & Itaguaí & No \\
\hline 16 & & Energy & Electricity transmission lines & Itaboraí & No \\
\hline 17 & & $\begin{array}{l}\text { Waste } \\
\text { treatment }\end{array}$ & Land emissary & Itaboraí & No \\
\hline 18 & & Energy & $\begin{array}{l}\text { Electricity transmission } \\
\text { lines }\end{array}$ & $\begin{array}{l}\text { Campos dos } \\
\text { Goytacazes }\end{array}$ & Yes \\
\hline 19 & \multirow{8}{*}{2011} & Mining & Limestone extraction & Cantagalo & Yes \\
\hline 20 & & $\begin{array}{l}\text { Waste } \\
\text { treatment }\end{array}$ & Industrial landfill & Macaé & Yes \\
\hline 21 & & Port & Maritime terminal & Mangaratiba & No \\
\hline 22 & & Port & Maritime terminal & Rio de Janeiro & No \\
\hline 23 & & Infrastructure & Subway & Rio de Janeiro & Yes \\
\hline 24 & & Construction & Dredging & Rio de Janeiro & No \\
\hline 25 & & Port & Port terminal & Rio de Janeiro & No \\
\hline 26 & & Port & Port terminal & São João da Barra & No \\
\hline 27 & \multirow{7}{*}{2012} & Energy & $\begin{array}{l}\text { Small hydroelectric power } \\
\text { station }\end{array}$ & Areal & No \\
\hline 28 & & Infrastructure & Paved road construction & Duque de Caxias & No \\
\hline 29 & & Oil and gas & $\begin{array}{l}\text { Natural gas processing - } \\
\text { Lubricant }\end{array}$ & Itaboraí & No \\
\hline 30 & & $\begin{array}{l}\text { Waste } \\
\text { treatment }\end{array}$ & Landfill & Magé & No \\
\hline 31 & & Allotment & Real estate development & Maricá & No \\
\hline 32 & & Allotment & Real estate development & Resende & No \\
\hline 33 & & Infrastructure & Highway construction & Rio de Janeiro & No \\
\hline
\end{tabular}


Table 1. Continued.

\begin{tabular}{|c|c|c|c|c|c|}
\hline ID & Year & Industry & Activity & Municipality & $\begin{array}{l}\text { Consider } \\
\text { terrestrial } \\
\text { invertebrate? }\end{array}$ \\
\hline 34 & \multirow{13}{*}{2013} & Hospitality & Hotel building & Arraial do Cabo & No \\
\hline 35 & & $\begin{array}{l}\text { Waste } \\
\text { treatment }\end{array}$ & $\begin{array}{l}\text { Waste treatment and } \\
\text { disposal }\end{array}$ & Belford Roxo & No \\
\hline 36 & & Mining & Sand extraction & Cabo Frio & No \\
\hline 37 & & Allotment & Industrial allotment & Cabo Frio & No \\
\hline 38 & & Dam & Dam & Cachoeira de Macacu & No \\
\hline 39 & & $\begin{array}{l}\text { Waste } \\
\text { treatment }\end{array}$ & Landfill & Duque de Caxias & No \\
\hline 40 & & Mining & Marble extraction & Itaperuna & No \\
\hline 41 & & Allotment & Industrial allotment & Macaé & No \\
\hline 42 & & Port & Port terminal & Macaé & Yes \\
\hline 43 & & Allotment & Real estate development & Petrópolis & No \\
\hline 44 & & Allotment & Real estate development & Rio das Ostras & No \\
\hline 45 & & Construction & Bus station & Rio de Janeiro & No \\
\hline 46 & & Port & Port terminal & $\begin{array}{l}\text { São Francisco de } \\
\text { Itabapoana }\end{array}$ & No \\
\hline 47 & \multirow{11}{*}{2014} & Mining & Sand extraction & Cabo Frio & No \\
\hline 48 & & Energy & Electricity transmission lines & Duque de Caxias & No \\
\hline 49 & & Naval & Pier expansion & Itaguaí & Yes \\
\hline 50 & & Construction & $\begin{array}{l}\text { Industrial and logistic } \\
\text { complex }\end{array}$ & Macaé & Yes \\
\hline 51 & & Allotment & Real estate development & Macaé & No \\
\hline 52 & & Energy & $\begin{array}{l}\text { Small hydroelectric power } \\
\text { station }\end{array}$ & Macaé & No \\
\hline 53 & & Construction & Real estate development & Maricá & Yes \\
\hline 54 & & Port & Port terminal & Maricá & No \\
\hline 55 & & Infrastructure & Highway construction & Niterói & No \\
\hline 56 & & Allotment & Real estate development & São João de Meriti & No \\
\hline 57 & & $\begin{array}{l}\text { Waste } \\
\text { treatment }\end{array}$ & Landfill & Volta Redonda & No \\
\hline 58 & \multirow{6}{*}{2015} & $\begin{array}{l}\text { Waste } \\
\text { treatment }\end{array}$ & Landfill & Macaé & No \\
\hline 59 & & Allotment & Real estate development & Maricá & No \\
\hline 60 & & Construction & Industrial complex & Paracambi & No \\
\hline 61 & & Infrastructure & Dredging & Rio de Janeiro & No \\
\hline 62 & & $\begin{array}{l}\text { Waste } \\
\text { treatment }\end{array}$ & Landfill & São Pedro da Aldeia & No \\
\hline 63 & & Energy & Power plant & Volta Redonda & No \\
\hline 63 & 2016 & Port & Port expansion & Macaé & No \\
\hline 65 & \multirow{5}{*}{2017} & $\begin{array}{l}\text { Waste } \\
\text { treatment }\end{array}$ & Landfill & Barra Mansa & Yes \\
\hline 65 & & Energy & Power plant & $\begin{array}{l}\text { Campos dos } \\
\text { Goytacazes }\end{array}$ & No \\
\hline 67 & & $\begin{array}{l}\text { Waste } \\
\text { treatment }\end{array}$ & $\begin{array}{l}\text { Waste treatment and } \\
\text { disposal }\end{array}$ & Resende & No \\
\hline 68 & & Energy & Power plant & Rio de Janeiro & No \\
\hline 69 & & Oil and gas & Pipeline & São João da Barra & No \\
\hline 70 & \multirow{2}{*}{2018} & Port & Port expansion & Itaguaí & No \\
\hline 71 & & Port & Port terminal & Macaé & No \\
\hline
\end{tabular}


Only the Phylum Arthropoda was considered as terrestrial invertebrates in the environmental impact studies analyzed, contemplating the Class Insecta in all ten studies (IDs 2, 18, 19, 20, 23, 42, 49, 50, 53 and 65) and Arachnida in two studies, with two studies considered spider in the evaluation of fauna (19 and 20 ) and only one study considered scorpion (19). The insects of the Orders Diptera (flies and mosquitoes), Hymenoptera (ants), Coleoptera (beetles), Lepidopetra (butterflies and moths), Hemipetra (aphids), Orthopetra (crickets) and Odonata (dragonflies) were the most frequent in the analyzed studies (Figure 2).

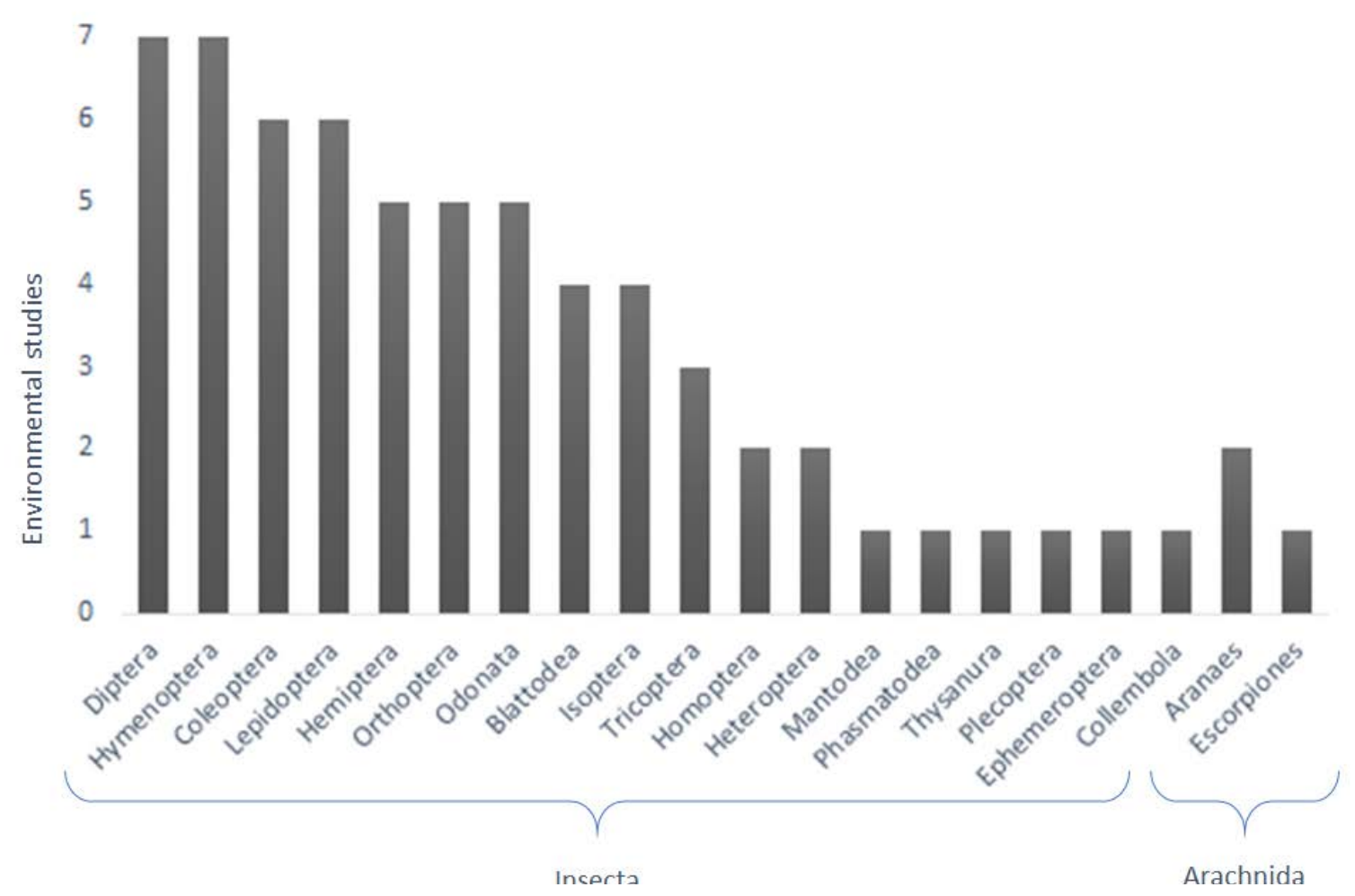

Figure 2. Arthropod Orders considered in fauna surveys of the analyzed environmental impact studies.

The most frequent method used in the survey of terrestrial invertebrate fauna was based on secondary data, with a review of specialized literature previously carried out in the area of influence of the projects $(2,18,42,49$, 50, 53 and 65). As the primary data source, the authors carried out field collections with pitfall (2), visual search $(19,20,23,49,53$ and 65$)$, aromatic baits (49 and 53), entomological nets $(49,53$ and 65), entomological umbrella (53) and light baits (65) (Figure 3). 


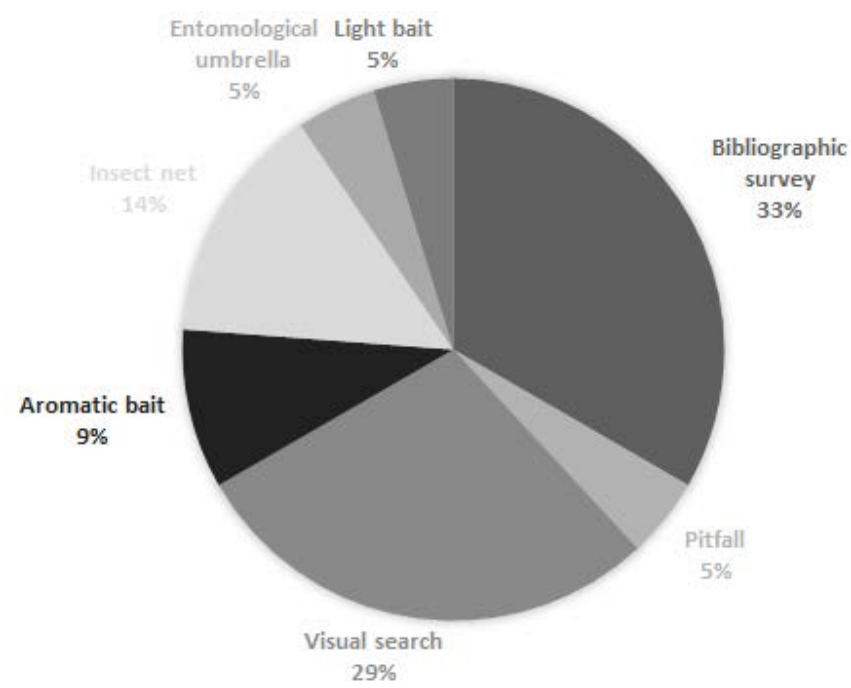

Figure 3. Methods used in the survey of terrestrial invertebrates' fauna of the analyzed environmental impact studies.

\section{Discussion}

Invertebrates constitute an animal group megadiverse and abundant in virtually every terrestrial and aquatic ecosystem, performing functions and providing services indispensable to the environment (Schowalter, 2006). Food webs fauna in the soil, for example, may affect positively cycling nutrients through fragmentation of organic matter and stimulate proliferation of decomposing organisms (Lavelle et al., 1993; Gartner and Cardon, 2004). Such a process, in turn allows the maintenance of the fertility of soils and primary productivity in ecosystems (Wardle, 1999). Invertebrates are agents of flower pollination (Isaacs et al., 2008; Pinheiro et al., 2008), seed dispersal and predation (Parr et al., 2007; Lomov et al., 2009), which are essential plant reproduction and distribution. In addition, constitute food resources of several other animals (Gunnarsson, 2008) and act (in the case of predators and parasitoids) in the control of agricultural pests (Landis et al., 2008; Gardiner et al., 2009).

Even though invertebrates are a megadiverse group, our results showed that less than $15 \%$ of environmental impact studies submitted to the state environmental agency in the Rio de Janeiro considered terrestrial invertebrates. The low percentage shows that terrestrial invertebrates have been neglected in environmental impact studies, which implies the effective management of the biodiversity conservation in ecosystems dominated by the Atlantic Rainforest, considered a hot spot of global biodiversity. The lack of knowledge of terrestrial invertebrate fauna, that is affected by industrial projects, limits the elaboration of conservationist strategies which impact the whole ecosystem.

The inventory must contain a complete description of fauna and flora, taking into account ecological interactions, and that there are two methods for this characterization: the qualitative one, which consists mainly of evaluating the richness of the species of the community, and the quantitative, which has as its main objective the analysis of the number of species and their population size (Silveira, 2006). A major problem with inventory surveys is the lack of information on invertebrate animals, which do not provide insight into the completeness of the complex interaction of local biodiversity. 
Normally in surveys, EIAs select the taxa to be sampled and almost always choose birds and mammals in fauna and flora, tree species, which considerably limits the quality of the studies, especially regarding biodiversity and interactions between species in a given ecosystem (Santos, 2003). In general, and especially in Brazil, the description of invertebrate biodiversity in biological communities has been restricted to classical quantitative aspects such as taxa composition, richness indices, equitability and morphospecies diversity, such as Simpson and Shannon Wiener (Corrêa et al., 2006; Podgaiski et al., 2007; Campos et al., 2009). Although traditional, these taxonomic indicators assume an equal functional weight for all species in the community, regardless of their characteristics, requirements and functions.

This results revealed that only the arthropod group was identified in environmental impact studies considering terrestrial invertebrate fauna. The insects were the most representative, being considered in all studies that surveyed the invertebrate fauna. Spiders and scorpions were considered in less than $3 \%$ of studies. Over a decade's time, environmental impact studies of industrial projects with potential environmental impact on Atlantic Rainforest ecosystems have disregarded the megadiversity of terrestrial invertebrates, so abundantly present in the Atlantic Rainforest ecosystems. The invertebrate animals are distributed by 33 Phylum (number that may vary depending on the adopted classification), gathering $95 \%$ of the known species (MMA, 2000). The other $5 \%$ belong to a single Phylum, the Vertebrates. Most invertebrate Phylum are exclusively marine, some are predominantly marine and the rest predominantly terrestrial. The arthropods that our results revealed to be the only invertebrates considered in the environmental impact studies constitute only one of the terrestrial invertebrate group, which is still constitute by Acanthocephala, Tardigrada, Onychophora, Platyhelminthes, Nematoda, Annelida and Mollusca. Due in part to its megadiversity in the world's diverse ecosystems, terrestrial invertebrate fauna remains to some extent unknown; it is estimated that potentially over $80 \%$ of existing arthropod species are not taxonomically described (Hammond, 1992; Redak, 2000). This lack of information is more restricted to some regions and/or taxa to the detriment of others (Barratt et al., 2003) and, especially in Brazil, has been attributed to the lack of sampling and especially taxonomist (Brandão et al., 2003).

Our results indicated that the most used method of obtaining the data in the analyzed environmental impact studies was the collection of secondary data, through the specialized literature review (bibliographic survey). The bibliographic survey was performed considering the places of installation of the industrial projects. The secondary data survey also considered information on terrestrial invertebrate species deposited in Zoological Collections for the same areas. The main shortcoming of secondary data for faunal inventories in environmental impact studies is due to the precariousness of information available. There is a strong relationship between the arthropods considered in the analyzed studies and the number of published studies on insects in the industrial project areas: in the few studies that considered terrestrial invertebrates, they were considered insects only because these animals have the most published studies. On the other hand, invertebrates with scarce published studies were not considered in environmental assessments, for example Annelida and Mollusca. The authors' lack of interest in carrying out fieldwork for the effective survey of terrestrial invertebrate fauna in environmental impact studies reinforces the need to improve methodological procedures 
aimed at completing the qualification of fauna present in the study area.

Conservation initiatives have evolved from focusing on species or groups of species threatened by various factors for a more comprehensive approach in which the effects of species sets are examined, or even of certain species, about processes of ecosystems. With this shift in emphasis, species are approached not only as subjects affected by environmental conditions or changes, but also as agents that modify or oppose such changes (Lewinsohn, 2005). Comparative studies of soil organisms under different conditions or regimes offer clear opportunities to assess the effects of changes in wealth or in the composition of species on ecosystems but, few investigations have set out to go so far. However, the importance of such analyzes for conservation is becoming more apparent as the maintenance of functional ecological entities is perceived as a prerequisite for conservation in long term.

\section{Conclusion}

The State of Rio de Janeiro is fully inserted in the Atlantic Rainforest, a biome considered a hot spot of global biodiversity, which houses a great diversity of fauna and flora. In the present analysis, environmental impact studies were evaluated during a decade of implementation of industrial projects. Less than $15 \%$ of environmental impact studies submitted to the state environmental agency considered terrestrial invertebrates. Among the studies that considered terrestrial invertebrates, only arthropods were listed. Considering only arthropods, the authors neglected other groups of terrestrial invertebrates important for environmental health, such as Annelida and Mollusca. The lack of interest in the conservation of terrestrial invertebrates demonstrates the fragility of the public authorities in issues related to biodiversity conservation strategies and exposes the urgent need for investment in the formation of human resources specialized in biodiversity conservation, especially of the terrestrial invertebrate groups that are forgotten in the environmental management agenda.

\section{Conflict of interests}

Authors declare that they have no conflict of interests.

\section{References}

Almeida, A. N.; Oliveira, N. B.; Silva, J. C. G. L.; Angelo, H. Principais deficiências dos estudos de impacto ambiental. Revista Brasileira de Gestão Ambiental e Sustentabilidade, v. 3, no. 4 , p. $3-14$, 2016. https://doi.org/ 10.21438/rbgas.030401

Almeida, A. N.; Rodrigues, N. G.; Vieira, L. C. G.; Couto Jr., A. F. Problemas nos estudos de impacto ambiental de rodovias e ferrovias. Revista Brasileira de Gestão Ambiental e Sustentabilidade, v. 6 , no. 12 , p. 129-136, $2019 . \quad$ https://doi.org/10.21438/rbgas. 061210

Almeida, A. N.; Silva Junior, L. H.; Nunes, A.; Angelo, H. Determinantes da qualidade dos Estudos de Impacto Ambiental. Revista Eletrônica em Gestão, Educação e Tecnologia Ambiental, v. 19, no. 2, p. 442450, 2015. https://doi.org/10.5902/ 2236117016651

Attanasio Jr., M. R. Direito Ambiental Interdisciplinar: para estudantes e profissionais das áreas de Ciência e Tecnologia. Campinas: Millennium, 2015.

Barrat, B. I. P.; Derraik, J. G. B.; Rufaut, C. G.; Goodman, A. J.; Dickinson, K. J. M. Morphospecies as a substitute for Coleoptera species identification, and the value of experience in improving accuracy. Journal of the Royal Society of New Zealand, v. 33, p. 583-590, 2003. https://doi.org/10.1080/ 03014223.2003 .9517746

Brandão, C. R. F.; Cancello, E. M.; Yamamoto, C. I. Invertebrados terrestres. In: Lewinsohn, T. M. (Org.). Avaliação do estado do conhecimento da biodiversidade brasileira: sumário executivo. Brasília: MMA, 2003. p. 1-64. 
Brasil. Lei no 6.938 , de 31 de agosto de 1981. Dispõe sobre a Política Nacional do Meio Ambiente, seus fins e mecanismos de formulação e aplicação, e dá outras providências. Available from: <http://www.planalto.gov.br/ccivil_03/LEIS /L6938compilada.htm>. Accessed on: Oct. 15, 2019.

Brasil. CONAMA Resolution 1, January 23, 1986. Establishes provisions for the basic criteria and general directives for the assessment of environmental impact. Available from: <http://www2.mma.gov.br/ port/conama/processos/61AA3835/CONAM A-ingles.pdf\#page $=768>$. Accessed on: Oct. $15,2019$.

Brasil. CONAMA Resolution 237, December 19, 1997. Establishes provisions for the revision and complementation of procedures and criteria used for the granting of environmental licenses. <http://www2.mma. gov.br/port/conama/processos/61AA3835/ CONAMA-ingles.pdf\#page $=775>$. Accessed on: Oct. 15, 2019.

Campos, L. A.; Bertolin, T. B. P.; Teixeira, R. A.; Martins, F. S. Diversidade de Pentatomoidea (Hemiptera, Heteroptera) em três fragmentos de Mata Atlântica no sul de Santa Catarina. Iheringia, v. 99, p. 165-171, 2009. https://doi.org/10.1590/S0073-47212009 000200008

Corrêa, M. M.; Fernandes, W. D.; Leal, I. R. Diversidade de formigas epigéicas (Hymenoptera: Formicidae) em capões do Pantanal Sul Matogrossense: relações entre riqueza de espécies e complexidade estrutural da área. Neotropical Entomology, v. 35, no. 6, p. 724-730, 2006. https://doi. org/10.1590/S1519-566X2006000600002

Duarte, C. G.; Dibo, A. P. A.; Sanchez, L. E. 0 que diz a pesquisa acadêmica sobre Avaliação de Impacto e Licenciamento Ambiental no Brasil? Ambiente \& Sociedade, v. 20, n. 1, p. 245-278, 2017. https://doi.org/10.1590/ 1809-4422asoc20150268r1v2012017

Fundação SOS Mata Atlântica. Atlas dos remanescentes florestais da Mata Atlântica: período 2015-2016. São Paulo: SOS Mata Atlântica, Instituto Nacional de Pesquisas Espaciais, 2017.

Garcia, D. C.; Candini, Giovano. Diagnóstico dos inventários de fauna em estudos de impacto ambiental de aterro sanitário.
Revista Brasileira de Ciências Ambientais, v. 45 , p. $100-114,2017$. https://doi.org/ 10.5327/Z2176-947820170236

Gardiner, M. M.; Landis, D. A.; Gratton, C.; Difonzo, C. D.; O’Neal, M.; Chacon, J. M., Wayo, M. T.; Schmidt, N. P.; Mueller, E. E.; Heimpel, G. E. Landscape diversity enhances biological control of an introduced crop pest in the north-central USA. Ecological Applications, v. 19 , p. 143-154, 2009. https://doi.org/ 10.1890/07-1265.1

Gartner, T. B.; Cardon, G. Decomposition dynamics in mixed-species leaf litter. Oikos, v. 104 , p. $230-246,2004$. https://doi.org/ 10.1111/j.0030-1299.2004.12738.x

Gunnarsson, B. Bird predation on spiders: ecological mechanisms and evolutionary consequences. The Journal of Arachnology, v. 35 , p. 509-529, 2008. https://doi.org/ 10.1636/RT07-64.1

Hammond, P. M. Species inventory. In: Groombridge, B. (Ed.). Global biodiversity: Status of the Earth's living resources. London: Chapman and Hall, 1992. p. 17-39.

Isaacs, R.; Tuell, J.; Fiedler, A.; Gardiner, M. M.; Landis, D. Maximizing arthropod-mediated ecosystem services in agricultural landscapes: The role of native plants. Frontiers in Ecology and Environment, v. 7, p. 196-203, 2008. https://doi.org/ $10.1890 / 080035$

Lacy, S. N.; Meza, F. J.; Marquet, P. A. Can environmental impact assessments alone conserve freshwater fish biota? Review of the Chilean experience. Environmental Impact Assessment Review, v. 63, p. 87-94, 2017. https://doi.org/10.1016/j.eiar.2016.12.006

Landis, D. A.; Gardiner, M. M.; Van Der Werfb, W.; Swintonc, S. M. Increasing corn for biofuel production reduces biocontrol services in agricultural landscapes. PNAS, v. 105, p. 20552-20557, 2008. https://doi.org/ 10.1073/pnas.0804951106

Lavelle, P.; Blanchart, E.; Martin, A.; Martin, S.; Barois, S.; Toutain, F.; Spain, A; Schaefer, R. A hierarchical model for decomposition in the terrestrial ecosystem: Application to soil in the humid tropics. Biotropica, v. 25, p. 130-150, 1993. https://doi.org/10.2307/ 2389178

Lewinsohn, T. M.; Freitas, A. V. L.; Prado, P. I. Conservação de invertebrados terrestres e 
seus habitats no Brasil. Megadiversidade, v. 1, no. 1, p. 62-69, 2005.

Lomov, B.; Keith, D. A.; Hochuli, D. F. Linking ecological function to species composition in ecological restoration: Seed removal by ants in recreated woodland. Austral Ecology, v. 34, p. 751-760, 2009. https://doi.org/ 10.1111/j.14429993.2009.01981.x

O'Faircheallaigh, C. Public participation and environmental impact assessment: Purposes, implications, and lessons for public policy making. Environmental Impact Assessment Review, v. 30, p. 19-27, 2010. https://doi.org/10.1016/j.eiar.2009.05.001

Oliveira, A. A.; Bursztyn, M. Avaliação de impacto ambiental de políticas públicas. Interações: Revista Internacional de Desenvolvimento Local, v. 2, n. 3, p. 45-56, 2001.

Parr, L.; Andersen, A. N.; Chastagno, C.; Duffaud, C. Savanna fires increase rates and distances of seed dispersal by ants. Oecologia, v. 151, p.33-41, 2007. https://doi.org/10.1007/s00442-006-0570-5

Pinheiro, M.; Abrão, B. A. E.; Harter-Marques, B.; Miotto, S. T. S. Floral resources used by insects in a grassland community in Southern Brazil. Brazilian Journal of Botany, v. 31, no. 3, p. 469-489, 2008. https://doi.org/ 10.1590/S0100-84042008000300011

Podgaiski, L. R.; Ott, R.; Rodrigues, E. N. L. R.; Buckup, E. H.; Marques, M. A. L. Araneofauna (Arachnida; Araneae) do Parque Estadual do Turvo, Rio Grande do Sul, Brasil. Biota Neotropica, v. 7, p.197-212, 2007. https://doi.org/10.1590/S1676-06032 007000200023

Redak, R.A. Arthropods and multispecies habitat conservation plans: Are we missing something? Environmental Management, v. 26 , p. $97-107,2000$. https://doi.org/ $10.1007 / \mathrm{s} 002670010065$

Sánchez, L. E. Avaliação de impacto ambiental: conceitos e métodos. 2. ed. São Paulo: Oficina de Textos, 2013.
Santos, A. J. Estimativas de riqueza em espécies. In: Cullen Jr., L.; Rudran, R.; Valladares-Padua, C. (Eds.). Métodos de estudos em Biologia da Conservação e manejo da vida silvestre. Curitiba: Editora UFPR, 2003. p. 19-41.

Scherer, M. Análise da qualidade técnica de estudos de impacto ambiental em ambientes de mata atlântica de Santa Catarina: abordagem faunística. Biotemas, v. 24, no. 4, p.171-181, 2011. https://doi.org/10.5007/ 2175-7925.2011v24n4p171

Schowalter, T. D. Insect Ecology: An ecosystem approach. San Diego: Academic Press, 2006.

Silveira, R. L. Avaliação dos métodos de levantamento do meio biológico terrestre em estudo de impacto ambiental para a construção de usinas hidrelétricas na região do cerrado. São Paulo: Escola Superior de Agricultura "Luiz de Queiroz", Universidade de São Paulo, 2006. (Master dissertation).

Thompson, G. G. Terrestrial vertebrate fauna surveys for the preparation of environmental impact assessments; how can we do it better? A Western Australian example. Environmental Impact Assessment Review, v. 27, no. 1, p. 41-61, 2007. https://doi.org/10.1016/j.eiar.2006.08.001

Wardle, D. A. How soil food webs make plants grow. Trends in Ecology and Evolution, v. 14 , p. 418-420, 1999. https://doi.org/ 10.1016/S0169-5347(99)01640-7

Wegner, A.; Moore, S. A.; Bailey, J. Consideration of biodiversity in environmental impact assessment in Western Australia: Practitioner perceptions. Environmental Impact Assessment Review, v. 25, no. 2, p. 143-162, 2005. https://doi.org/10.1016/j.eiar.2004.03.003 